DOI: https://doi.org/10.20535/2707-2096.6.2021.241795

UDC 622.284.74(574.3)

\author{
S. Barsukov, Doctoral student \\ A.T. Batyrkhanova, Doctoral student \\ V.F. Dyomin *, Doc. Eng., Professor \\ ORCID: 0000-0002-1718-856X \\ Karaganda State Technical University, Karaganda, \\ Republic of Kazakhstan \\ *Corresponding author: Professor of the Department \\ "Mining of mineral deposits" \\ of Karaganda State Technical University \\ baydildinova_a@mail.ru \\ Received 17.09.2021; Accepted 05.10.2021
}

\title{
DETERMINING THE PATTERNS OF STABILITY OF MINE WORKINGS FOR CALCULATION ROOF BOLTING PARAMETERS
}

Purpose. The published studies are aimed at determining the mechanism of deformation of the rocks of the contour around the workings in terms of the parameters of the emerging fracturing and their dependence on the indicators of the strength of the rocks and the depth of occurrence in the massif. The tasks of the study include the installation of fracture indicators, the determination of the parameters of the development of the deformation process around the working, including the effect of longwall mining and taking into account the possibility of reuse of the workings.

Methodology. To solve the set tasks, the method of field observations was used together with the use of regression dependencies to determine the dependences of the parameters on the influencing factors. In addition, the method of full-scale pull-out tests of anchor support was used, which made it possible to determine the clamping forces of the anchors.

Originality. In the course of the research, the dependences of stresses and deformation along the K7 coal seam in the conditions of the mine named after Kuzembaev CD JSC "ArcelorMittal Temirtau" for the massif around the mine with fastening. Rational parameters for the use of roof bolting in preparatory mine workings have been established. This type of fastening provides direct contact between rocks and lining. Analysis of the results of calculating the parameters of the roof bolting showed that to maintain the roof in the development workings, it is necessary to take into account the parameters of the roof bolting. The main parameters include the length of the anchors, the total resistance of the roof bolting and the density of the anchors. Anchor support forms laminated rock beams in the roof rocks, which ensure the stability of the workings.

Conclusions and practical significance. The results of studies devoted to the establishment of the influence of mining-geological and mining-technical factors on the formation of zones of inelastic deformation in the host rocks were considered. Significant dependences of the deformation processes of rocks in the massif around the workings were obtained, and the parabolic zone of destruction of rocks was determined. The practical significance of the research consists in determining the actual indicators of the required bearing capacity of the anchorage at two levels in the conditions of the development of the coal seam $k 7$ of the Kuzembaev mine.

Keywords: deformation, coal-stone, array, working out, parameters, strength, tension, technology, anchor, support. 


\section{INTRODUCTION}

The wide proliferation of anchoring type for various geological and mining conditions of field development [1-3] allows to determine the peculiarity of this type of structures as universal, which has the prospect of application in the conditions of underground field development, and the development of combined structures allows covering most geotechnical conditions of mining practice. Confirmation of the priority of this direction of development is the latest achievements of the mining industry in England [1,4], where the spread of anchoring types has reached prevailing importance.

\section{THE MAIN PART}

Cracking in the roof and walls in the range of depths of the working location from 500 to $700 \mathrm{~m}$ differs slightly and begins after 0.4 hours at the depth of $1.2-1.5 \mathrm{~m}$ in the marginal rocks and with the study period of 1.5, 15 and 150 days is spread in increments of $0.2 \mathrm{~m}$ deep into the massif. In the soil the tendency of crack propagation is similar to cracking in the roof: with the same parameters but at the initial distance of $1.5 \mathrm{~m}$ from the contour of development.

At the depth of 800 and $1000 \mathrm{~m}$, in the roof the process of the onset of cracking is shifted deeper into the massif compared to the depth of 500-700 $\mathrm{m}$ by $0.5-0.6 \mathrm{~m}$ (up to $1.7-2.1 \mathrm{~m}$ ), and in the soil by $1.5-2.0 \mathrm{~m}$ and begins at the distance of $2.5-3.5 \mathrm{~m}$. Cracking in the roof and walls of the working depends on the depth in the directly proportional relationship, and in the soil it spreads by a hyperbolic connection. With increasing the development depth (from 600 to $1000 \mathrm{~m}$ ), crack formation increases 1.5 times. The first curves of conditional zones of inelastic deformations from the contour of the working are located at the distance of 1.6-2.0 m.

The development of cracking in time $\left(R_{\mathrm{T}}\right)$ depending on the depth of location $(H)$ by the roof bolting:

for the roof and walls

$$
\begin{aligned}
& R_{m}=1.03+0.0005 H+0.06 T, \\
& R_{m}=1.4+0.0005 H+0.1 T, \mathrm{~m} .
\end{aligned}
$$

for the floor

The dependence of the depth of crack propagation $\left(R_{\mathrm{T}}, \mathrm{m}\right)$ in the enclosing rocks depending on the angle of incidence of the formation ( $\alpha$, deg.) has been determined as well as controllability of the roof $\operatorname{rocks}\left(\frac{\boldsymbol{H}_{\boldsymbol{H . \kappa .} \cdot}}{\boldsymbol{m}}\right)$ :

$$
\begin{aligned}
& R \mathrm{~T}=1.1+0.07 \frac{\boldsymbol{H}_{\text {нк. }}}{\boldsymbol{m}}, \\
& R=1.9+0.06 \alpha, \mathrm{m} .
\end{aligned}
$$

The working contour shift depending on the distance to the breakage face

There has been established the empirical dependence of the value of convergence $(C, \mathrm{~m} /$ day $)$ and the intensity of deformation $\left(R_{д}, \mathrm{~m}\right)$ of the roof rocks:

$$
\begin{aligned}
& C(l)=-2 \cdot 10^{-3} \cdot L+8,8 \cdot 10^{-3}, \\
& R(l)=-0.04 \cdot \sqrt[3]{L}+0,25 .
\end{aligned}
$$

The roof rock shift $\Delta$ Uo around the development working in the zone of stoping impact, depending on the period of its supporting $(T)$ for the roof bolting change by the empirical dependence:

$$
\Delta U_{t}(T)=16,34 T^{0.291}
$$

The rock deformation $(U, \mathrm{~mm})$ in the development workings dependence on the depth of the development $(H, m M)$ for the roof bolting is:

$$
U(H)=8,3 H^{0.7} \text {. }
$$


There has been determined the empirical dependence of the walls shits $\left(B_{\sigma}\right)$ on the working width $\left(W_{6}\right)$ :

$$
B б(b)=0,09 \omega^{2}-0,7 \omega_{8}+2
$$

The empirical dependence of the deformation speed changing $(U, \mathrm{~mm} /$ day $)$ of the working roof rocks on the support bearing capacity $\left(R, t / m^{2}\right)$ is;

$$
U(R)=0,19 e^{-0.8 R}
$$

Manifestation of the rock pressure $(Q, k N)$ with the roof bolting in the development workings for the anchor rods made of reinforced steel $21.6 \mathrm{~mm}$ with the shifts $(N, \mathrm{~m})$ is:

$$
Q(U)=46 N^{0.4}
$$

When limited by the cracking limits, the shape of the fracture zones is parabolic (Figure 1). The parabolic shape means that the cross-sectional area, and, consequently, the mass per unit length of the working, is easy to calculate (area $=0.66 *$ width of the working $*$ height) [1]. Similarly, the height of the fracture depending on the distance from the centerline $=$ height $-4 *$ height/width of the working $^{2} *$ distance $^{2}$.

Figure 2 provides a graphic representation of the results for a number of coefficient $K$ values. The shape of the fracture zone can be used to determine the length of combined anchors, and the mass of the zone to determine their number.

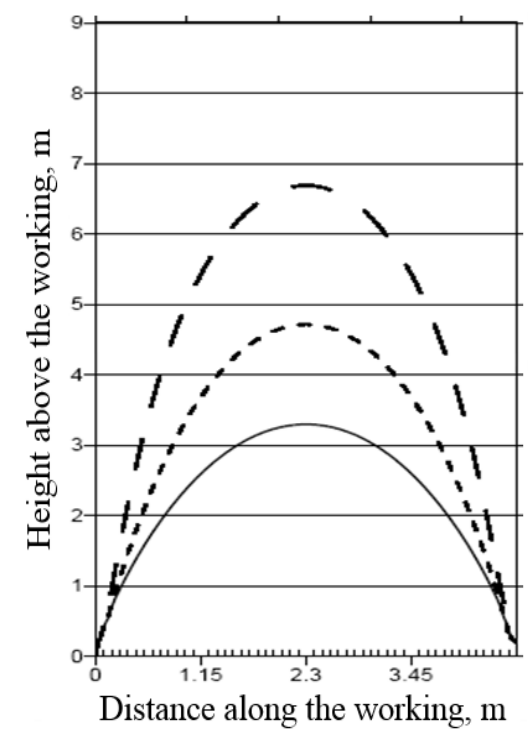

Figure 1 - Development of failure zones above the working roof

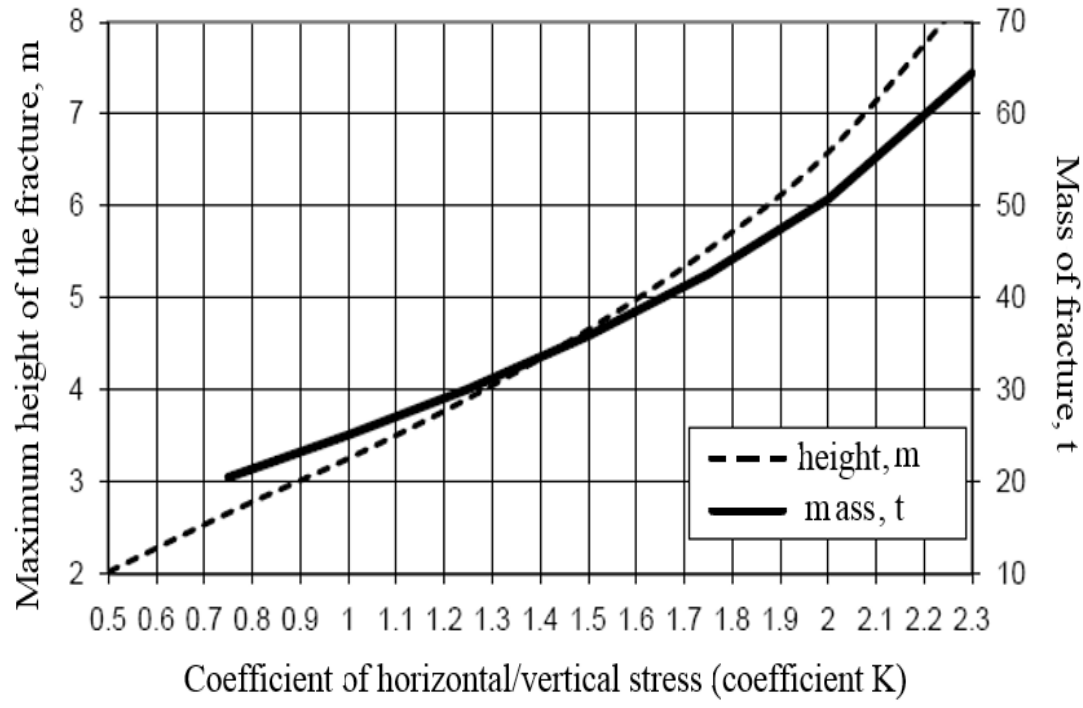

Figure 2-Graph of the stressed and overhung destroyed rock mass in the working roof

The depth of the working walls fracture on the coal is limited by the cracking limits. This means that the maximum depth of the working walls collapse is about $1 \mathrm{~m}$ independent on the depth (Figure $3)$.

The roof bolting with the anchor rod length in the range of 2.0-2.4 m, ensures the formation of an elastic layered rock beam. The second level of the roof bolting with the anchor rod length of $3.0 \mathrm{~m}$ and more is set at the distance of $0.1 N$ to the first long-wall face. This option provides for the reduction of the use of additional supporting hydraulic racks up to $80 \%$. 


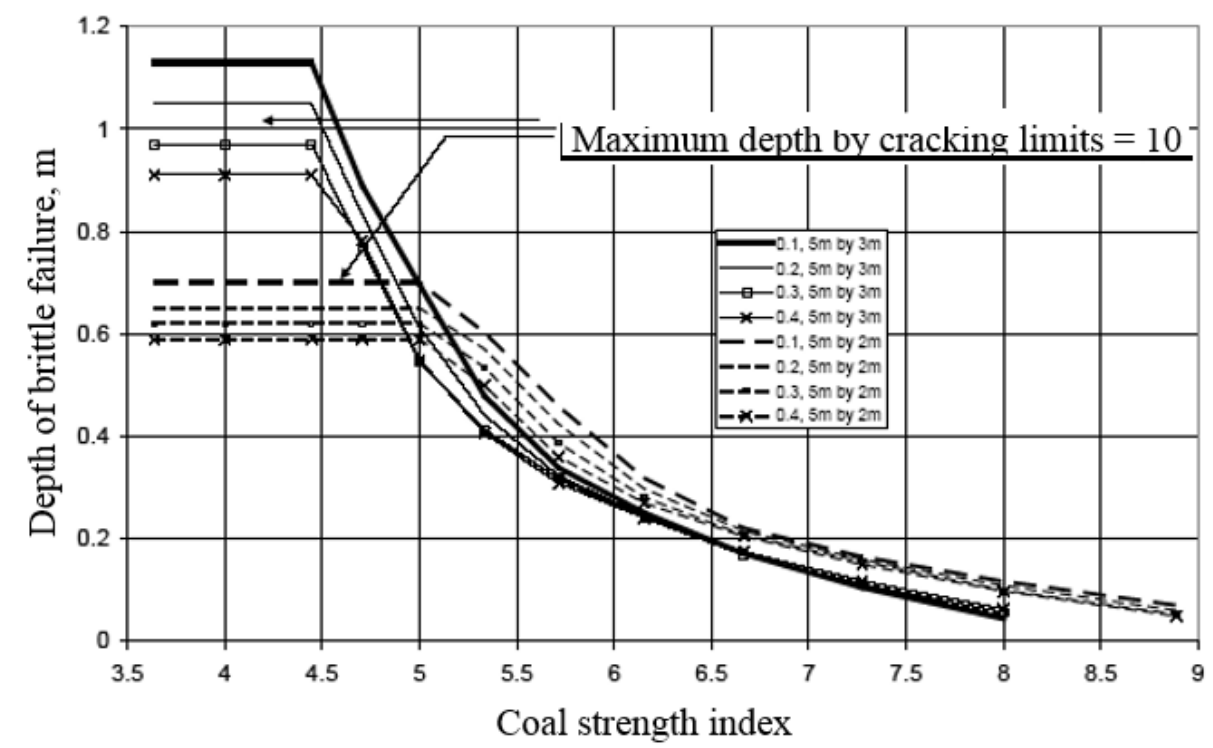

Figure 3 - Failure depth in the working walls

The layered rock strata of the roof with increasing shifts lose their bearing capacity. This circumstance must be considered when calculating the parameters of the roof bolting by introducing the coefficient of increasing the bearing capacity of the support [2]. The value of the coefficient of increasing the bearing capacity of anchors of the second level is 1.1-1.6 and is taken depending on the amount of displacement of roof rocks in the period between the mounting the roof bolting of the first level and the mounting of the roof bolting of the second level. The use of the coefficient of increasing the bearing capacity of the roof bolting of the second level in determining the parameters of the roof bolting is confirmed with the studies presented in Figure 4.

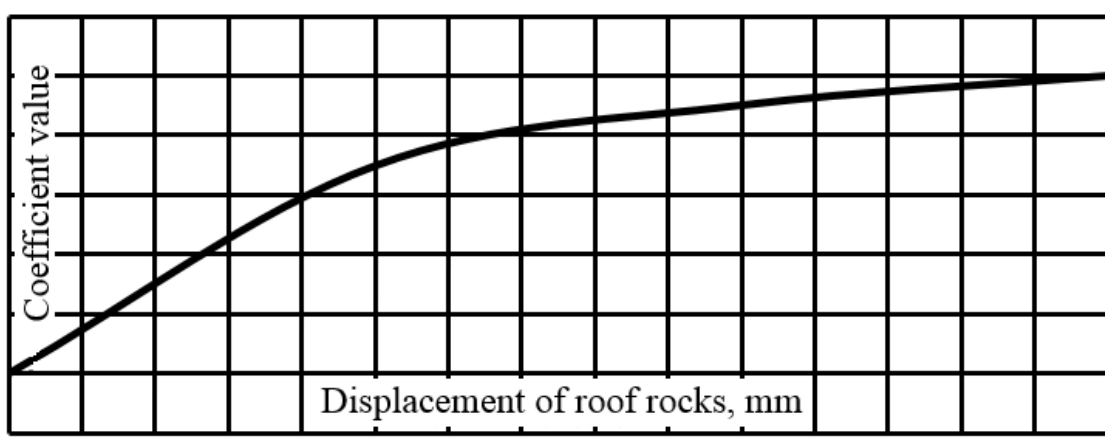

Figure 4-Rock thickness bearing capacity dependence on displacements
The consolidated bearing capacity of the system "layered massif - a twolevel pliable deep-laid roof bolting" largely depends on the dimensions of the sliding prisms in the walls of the working. To establish the mechanism of rock deformation in the walls of the workings and to determine the parameters of

the roof bolting mounted in the walls of the workings, the lateral thrust force and the length of the anchor rod were established:

$$
r=R+q-F_{m p}
$$

In equation (2.9) the lateral thrust force $R$ causing the working walls failure is determined by the formula:

$$
R=\left(K_{o} \gamma H_{c}\right) \cdot \lambda h_{6}
$$

where $K_{o}$ is the coefficient of the reference pressure concentration; $\gamma$ is the mean volumetric weigh of the massif; $H$ is the depth of the working laying from the surface; $\lambda$ is the lateral thrust coefficient; $h_{b}$ is the working height. 
The friction force $N_{m p}$ prevent from the failure rocks spalling in the working walls and are determined by the formula:

$$
N_{m p}=r\left[\exp \left(\frac{2 n_{m p} \cdot l_{p}}{\lambda \cdot m_{6}}\right)-1\right]
$$

where $r$ is the support resistance to spall; $n_{m p}$ is the coefficient of the friction between the seam and the roof and floor rocks; $l_{p}$ is the depth of the failure rocks zone in the working walls; $m_{b}$ is the thickness of the failure rocks in the working walls.

The maximum value of the spall rocks force in the working $q$ is determined by the expression:

$$
q=\gamma_{y} l_{p} h_{B} \lambda
$$

where $\gamma_{y}$ is the volumetric weight of the failure rocks in the working walls.

After the final transformations the required resistance of the roof bolting in the working walls can be determined by the formula:

$$
r=\frac{\left[\left(K_{o} \gamma H-\sigma_{c}\right) \cdot \lambda+\gamma_{y} l_{p} \lambda\right] \cdot h_{s}}{\exp \left(\frac{2 n_{m p} l_{p}}{\lambda \cdot m_{s}}\right)}
$$

The depth of the seam failure zone is determined by the formula:

$$
l_{p \max }=\frac{\left\{\lg \left[\left(K_{o} \gamma H-\sigma_{c}\right) \cdot \lambda+r\right]-\lg r\right\} \cdot \lambda \cdot h_{b}}{2 n_{m p} \lg e}
$$

The analysis of the results allows concluding that it is impossible to exclude the wall rocks failure. The depths of anchoring the working walls is within the limits of 2,2-2.5 and more meters.

$$
H_{p . \sigma .}>\frac{R_{c \tilde{\sigma}}}{K_{o} 2 \gamma}
$$

where $R_{c \sigma}$ is the rock strength for uniaxial compression of the walls rocks.

At the same time it was found that at the depths significantly exceeding $H_{p . \sigma .}$, the width of the zone of the rocks failure in the walls 2.0-2.5 was times smaller than the width of the creeping prisms, and at the depths significantly exceeding more than their width 1.5-2.0 times. If you take at all depths exceeding $H_{p . \sigma}$. the same parameters of the roof bolting in the walls and in the roof, it will be contrary to the actual processes that develop in the rocks of the roof and the walls of the working [3].

According to the results of the mine tests for pulling out the anchor rods mounted under the conditions of volumetric compression, the pulling forces are $60-80 \mathrm{kN}$ and ensure retention of the creeping prism of the rocks in the walls of the workings. The mine tests for pulling out the anchor rods have established that the length of the anchor rods mounted in the walls of the workings is determined by the ultimate strength of the rocks for uniaxial compression, and the dependence is shown in Figure 5.

Frame supports do not practically have the required resistance to the displacement of the roof, which leads to decreasing the efficiency of its support with reinforcement racks. 


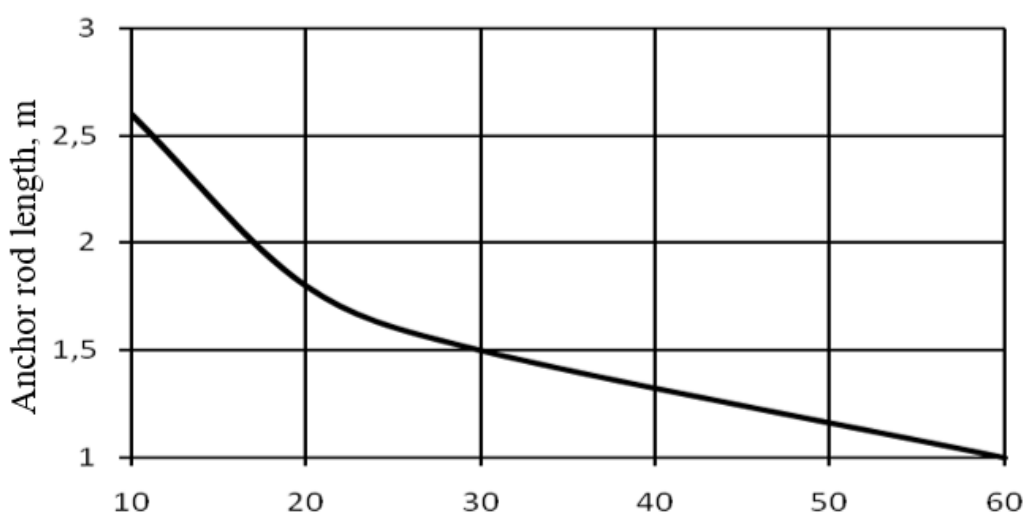

Rock ultimate strength for compressiob, $\mathrm{MPa}$

\section{Figure 5-Anchor rod length dependence on the rock limit strength for uniaxial compression in the zone of stoping impact}

The roof bolting provides a high-quality contact between the rocks and the support. The analysis of calculating the parameters of the roof bolting shows that to support the roof in the development workings, it is necessary to calculate the parameters of the roof bolting. The main parameters include the length of the anchors, the total resistance of the roof bolting and the density of the anchors. The roof bolting forms rock layered beams in the roof rock that ensure stability of the workings.

The layered roof fastened by anchor rods is a composite beam, the bearing capacity of which is determined by the resistance of the lower layers to tensile strength. It is assumed that the moment of resistance of the composite beam is always greater than the sum of the moments of resistance of individual layers, but lower than the moment of resistance of one beam, having a height equal to the stack of layers.

The use of a two-level roof bolting for supporting reused workings confirms the efficiency of supporting the rocks in the roof and walls of reused workings. In contrast to the base, on the experimental plots with a two-level support, the nature of deformation of the enclosing rocks changed, the support fully provided the working condition of the workings under study. After the approach of the long-wall face to the experimental sites, the main load of the shifting roof was perceived by the anchors and the roof bolting strips. The roof rocks and walls shifts from the side of the long-wall face gradually increased and reached $250-300 \mathrm{~mm}$. At the experimental sites, the workings with a twolevel roof bolting remained in working conditions without significant deformations.

As a result of performing a complex of laboratory, mine and analytical studies, geotechnological principles were developed for securing mine workings at all stages of their existence: from driving to reuse, while any main support for a development working is enhanced by additional pliable roof bolting with the anchor rod 3.0 meters or more which parameters are based on a comprehensive studying of the stress-strain state of the layered massif, evaluation of its own bearing capacity and the conditions of interaction with the support. This made it possible to solve the scientific and technical problem of ensuring stability of the development workings in the pillarless mining of flat seams at current rates of movement of the breakage and development faces.

The studies have established that the bearing capacity of the roof layered rock strata stitched with the roof bolting depends on the magnitude of the displacements at the time the mounting the roof bolting and decreases in the range of 50-200 mm displacement values by 10-60\%, respectively; the width of the creeping prisms of the deformed rocks in the walls of reusable workings is determined by the depth of the workings and is 2.2-5.2 m; a two-level roof bolting with the anchor rod length of 2.4-3.0 $\mathrm{m}$ and more determined by the strength of rocks and the working span, with the fastening force of 130-160 kN ensures a steady state of reused workings located in the zone of the stoping impact; a pliable roof bolting of the second level with the anchor rod length of 3.0 meters or more, in combination with the main roof bolting, protects the roof rocks from uncontrolled deformation, slows down the roof failure, and in combination with the strengthening support racks and security structures provides maintenance-free operation of reusable workings.

The maximum stress concentration occurs in the working contour or is shifted into the bulk of the massif if the rocks near the contour have increased deformability compared to the rest of the massif. 


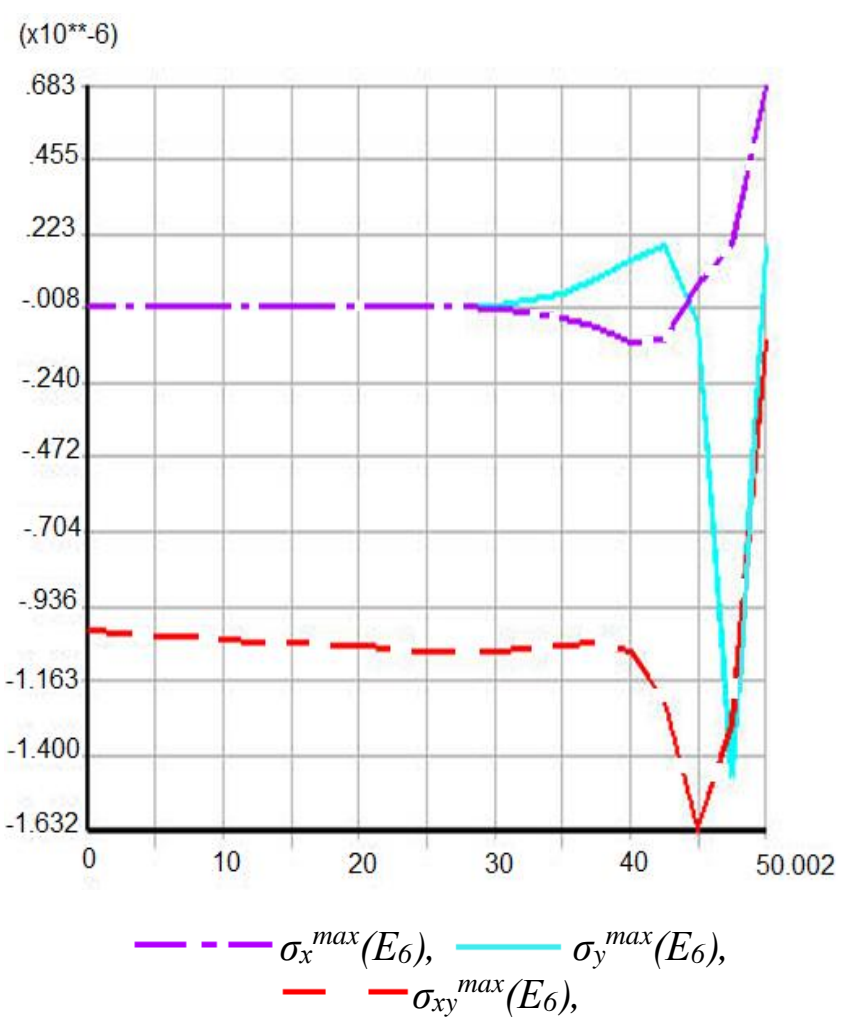

Figure 6-Deformation curves along the upper border of the coal seam $k 7$ of the Kuzembayev mine of $C D$ "ArcelorMittal Temirtau” JKC

The stress concentration weakens rapidly with moving deeper into the massif from the working contour. The dimensions of the zone of impact, i.e. the zone of the rock massif covered by the stress concentration depend on the dimensions of the working cross-section.

The simulation results (a single working with an arch support) indicate decreasing stresses in the walls and in front of the working, which contributes to reducing the likelihood of sudden outbursts [1].

In the course of the studies, the dependence of stresses and strains along the coal seam $\mathrm{k} 7$ was established in the conditions of the mine Kuzembaev mine of the CD "ArcelorMittal Temirtau" JSC, for the massif around the working with a support (Figure 6).

Having analyzed the results obtained, it has been established that the functional dependences $\sigma_{x}^{\max }\left(E_{6}\right), \sigma_{y}{ }^{\max }\left(E_{6}\right), \sigma_{x y}{ }^{\max }\left(E_{6}\right)$, $u_{x}^{\max }\left(E_{6}\right)$ do not depend on the elasticity modulus $E_{6}$. Exception is only dependence $u_{y}{ }^{\max }\left(E_{6}\right)$. form:

Dependence $u_{y}{ }^{\max }\left(E_{6}\right)$ has the following

$$
U_{y}=0,05+0,14 / E_{6}
$$

Based on the analysis of instrumental observations in outcrops of the extended workings of the mines of the Karaganda coal basin, there was established the rock strength effect on the distance between natural cracks in the rock massif. The values of the distances between the cracks can be found from the expression:

$$
l_{\text {cp }}=0,03 \mathrm{e}^{0,003 \mathrm{R}_{\varepsilon}}
$$

where $R_{c}$ is rock strength for uniaxial compression, $\mathrm{kg} / \mathrm{cm}^{2} ; l_{\mathrm{cp}}$ is the mean distance between the cracks, $\mathrm{m}$.

The studies carried out allow establishing the inpact of geological and mining factors on the formation of zones of inelastic deformations in the enclosing rocks, as well as establishing the rational parameters for the roof bolting use in the development mine workings

\section{CONCLUSIONS and practical significance}

As a result of the research, statistically reliable dependences of the parameters of deformation processes around excavations in the form of development of the zone of destruction of parabolic rocks were obtained. The practical significance of the publication lies in the determination of the actual indicators of the required bearing capacity of anchoring for the conditions of development of layers at the Mine them. Kuzembayeva.

\section{REFERENCES}

[1] Report on research work. Development and implementation of technologies for multi-purpose active supporting systems based on simulating stress state of the coal-rock massif around mine workings. Karaganda, 2016.

[2] A.Ye. Sudarikov, Fundamentals of Underground Structures Mechanics. Karaganda: KSTU, 2003. 
[3] I.V. Baklashov, Geomechanics. Fundamentals of geomechanics. M.: Publishing House of Moscow State Mining University, V. 1, 2014.

[4] I.V. Baklashov, Geomechanics. Geomechanical processes. M.: Publishing House of the Moscow State Mining University, V. 2, 2014.

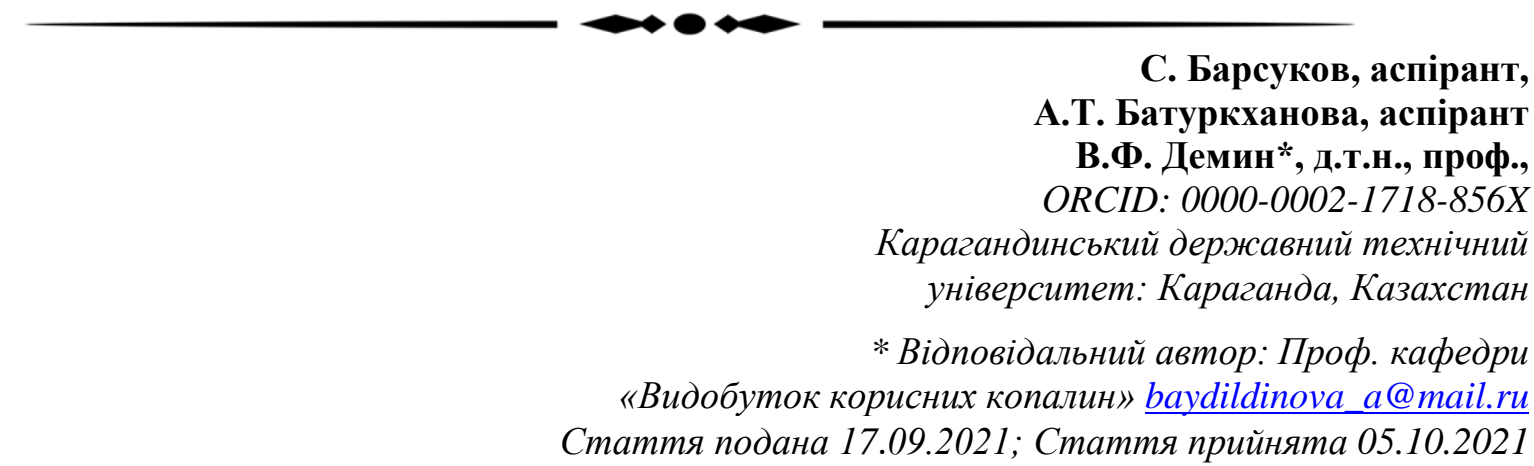

\section{ВИЗНАЧЕННЯ ЗАКОНОМІРНОСТЕЙ СТІЙКОСТІ ГІРНИЧИХ ВИРОБОК ДЛЯ РОЗРАХУНКУ ПАРАМЕТРІВ КРІПЛЕННЯ ПОКРІВЛІ}

Мета та завдання. Опубліковані дослідження мають на меті визначення механізму деформування порід контуру навколо виробок в частині параметрів виникає тріщинуватість і їх залежності від показників міцності порід і глибини залягання в масиві. До завдань дослідження віднесено встановлення показників тріщинуватості, визначення параметрів розвитку деформаційного процесу навколо виробки, в тому числі при впливі очисних робіт в лаві із урахуванням можливості повторного використання виробок.

Методи дослідження. Для вирішення поставлених завдань використані метод натурних спостережень спільно 3 застосуванням регресивних залежностей для визначення залежностей параметрів від впливаючих факторів. Крім того, використаний метод натурних випробувань анкерного кріплення на висмикування, що дозволило визначити зусилля затискання анкерів.

Наукова новизна. В ході досліджень встановлено залежності напружень і деформації уздовж вугільного пласта К7 в умовах шахти ім. Кузембаєва УД ОТ «АрселорМиттал Темиртау» для масиву навколо виробки з кріпленням. Встановлено раціональні параметри застосування анкерного кріплення в підготовчих гірничих виробках. Цей вид кріплення забезпечує безпосередній контакт порід і кріплення. Аналіз результатів розрахунку параметрів анкерного кріплення показав, що для підтримки покрівлі в підготовчих виробках необхідно враховувати параметри анкерного кріплення. До основних параметрів слід віднести довжину анкерів, загальний опір анкерного кріплення і щільність розміщення анкерів. Анкерне кріплення формує в породах покрівлі породні шаруваті балки, які забезпечують стійкість виробок.

Висновки та практичне значення. Були розглянуті результати досліджень присвячені встановленню впливу гірничо-геологічних і гірничотехнічних факторів на утворення зон непружних деформацій у вміщуючих породах. Були отримані значимі залежності деформаційних процесів порід в масиві навколо виробок, визначені зони руйнування порід. Практична значимість досліджень полягає у визначенні фактичних показників необхідної несучої здатності анкерного кріплення в двох рівнях в умовах розробки вугільного пласта К7 шахти ім. Кузембаєва.

Ключові слова: деформація, вугільно-кам'яна, масив, виробка, параметри, міцність, напруження, технологія, анкер, опора.

\section{СПИСОК ВИКОРИСТАНОЇ ЛІТЕРАТУРИ}

[1] Звіт про науково-дослідну роботу. Розробка та впровадження технологій багатоиільових активних допоміжних систем на основі моделювання напруженого стану вугільно-кам'яного масиву навколо гірничих виробок. Караганда, 2016.

[2] А.Я. Сударіков, Основи механіки підземних споруд. Караганда: КСТУ, 2003.

[3] І.В. Баклашов, Геомеханіка. Основи геомеханіки. М.: МДГУ, В. 1, 2014.

[4] І.В. Баклашов, Геомеханіка. Геомеханічні проиеси. М.: МДГУ, В. 2, 2014. 